\title{
Pelatihan dan Pendampingan Online dalam Penulisan Penelitian Tindakan dan Karya Tulis Imiah bagi Guru
}

\author{
Kadek Suranata \\ Universitas Pendidikan Ganesha, Bali, Indonesia
}

\section{Article Info \\ Article history: \\ Received Oct $21^{\text {th }}, 2020$ \\ Revised Oct $29^{\text {th }}, 2020$ \\ Accepted Nov $9^{\text {th }}, 2020$ \\ Published Nov 282020}

\section{Keyword:}

Community service

Online training

Action research

Scientific writting

\section{Corresponding Author:}

Kadek Suranata,

ఏ kadek.suranata@undiksha.ac.id

\begin{abstract}
This community service program is a online training and assistance in writing action research and scientific articles for teachers which aims to increase motivation and ability to write action research and scientific articles for teachers in Bali Province. The combination of the synchronize method through the Zoom application and unsynchronized method through the WhatsApp application was carried out for two weeks involving 85 elementary, junior, and high school teachers from various regions of Bali province. Evaluation of this program is measured through few indicators: (1) success in identifying problems and themes for action research, (2) success in formulating solutions to overcome problems, (3) success in drafting action research proposals, and (4) success in compiling a draft of action research articles. The evaluation results showed that (1) $90 \%$ of participants succeeded in compiling problem identification and research themes, $80 \%$ of participants succeeded in formulating solutions to overcome problems, (3) $80 \%$ of participants succeeded in compiling a draft proposal, and (4) $65 \%$ of participants have successfully drafted a scientific articles from their action research studies. This results indicate that online training and mentoring was quite successful in increasing teacher motivation and ability to compile action research and scientific articles.
\end{abstract}

(C) 2020 The Authors. Published by IICET

This is an open access article under the CC BY-NC-SA license

(https://creativecommons.org/licenses/by-nc-sa/4.0

\section{Pendahuluan}

Profesi guru sebagaimana diatur dalam Undang-Undang Nomor 14 Tahun 2005 disebut sebagai pendidik profesional dengan tugas utama membimbing, mengarahkan, melatih, menilai, dan mengevaluasi peserta didik pada pendidikan anak usia dini jalur pendidikan formal, pendidikan dasar, dan pendidikan menengah. Sama seperti profesi lainnya, profesi guru tentu memiliki peraturan atau ketentuanketentuan profesi yang berlaku serta mengikat anggotanya.

Dalam meningkatkan kualitas dan kesejahteraan guru dan mewujudkan guru yang profesional, pemerintah melakukan beragam upaya, salah satunya melalu program sertifikasi guru. Sebagaimana yang tertuang dalam Permendiknas No. 18 Tahun 2007, sertifikasi guru dilakukan dengan mengacu pada beberapa portofolio yakni (1) kualifikasi akademik; (2) pendidikan dan pelatihan; (3) pengalaman mengajar; (4) perencanaan dan pelaksanaan pembelajaran; (5) penilaian atasan dan pengawas; (6) prestasi 
akademik; (7) karya pengembangan profesi; (8) keikutsertaan dalam forum ilmiah; (9) pengalaman organisasi di bidang sosial dan kependidikan; dan (10) penghargaan yang relevan di bidang pendidikan.

Berdasarkan penjabaran portofolio tersebut, seorang guru profesional tidak hanya semata menguasai kompetensi dalam pembelajaran, namun juga mampu memiliki kemampuan dalam berbagai aspek. Terkait dengan pemenuhan poin portofolio ke-7 tentang karya pengembangan profesi, seorang tentu harus memiliki kompetensi untuk meneliti dan menulis karya ilmiah baik berupa buku, modul, maupun artikel ilmiah. Disamping untuk memenuhi portofolio terkait sertifikasi, kemampuan dan kemauan guru untuk meneliti dan menghasilkan karya tulis ilmiah akan sangat bermanfaat bagi pengembangan ilmu pengetahuan dan proses pendidikan.

Profesi guru sangat dekat dengan berbagai kegiatan yang mendukung penciptaan dan pengembangan pengetahuan ilmiah, seperti membaca, mendidik, mengobservasi, menganalisis, meneliti, dan sebagainya. Berbagai kegiatan ilmiah tersebut akan sangat bermanfaat bagi banyak pihak apabila ditulis serta dipublikasikan dengan baik. Salah satu kegiatan ilmiah yang populer dilakukan dikalangan profesi guru adalah penelitian tindakan kelas (PTK). Penelitian tindakan kelas merupakan jenis action research yang dilakukan oleh guru untuk mengidentifikasi permasalahan-permasalahan yang terjadi di kelas sekaligus memberi pemecahan masalahnya. Beberapa studi telah menemukan bahwa penelitian tindakan kelas penting untuk dilakukan oleh guru dalam upaya meningkatkan kualitas pembelajaran (Afandi, 2014; Ni'mah, 2017; Ridwan, 2017).

Selain bermanfaat bagi khalayak luas, kegiatan meneliti dan menulis karya ilmiah juga akan sangat bermafaat bagi guru sendiri. Kemauan guru untuk melaksanakan kegiatan ilmiah seperti melakukan penelitian serta melaporkan hasil penelitian tersebut dalam bentuk karya tulis ilmiah akan meningkatkan pengetahuan serta wawasan terkait dengan pengembangan ilmu pengetahuan dan kegiatan pembelajaran sehingga akan menunjang penguasaan kompetensi profesional guru. Perkembangan karir yang dimiliki oleh guru juga akan meningkat sejalan dengan peningkatan kompetensi guru dalam melakukan penelitian tindakan kelas dan melaporkan hasilnya melalu karya tulis ilmiah yang berkualitas.

Akan tetapi kenyataannya, karya tulis ilmiah yang dihasilkan oleh guru masih terbatas. Anggapan bahwa penelitian dan karya tulis ilmiah merupakan "pekerjaan sulit" masih melekat di benak kebanyakan guru. Kesulitan yang dialami oleh guru dalam menyusun karya tulis ilmiah dapat disebabkan oleh beragam faktor, baik internal maupun eksternal, termasuk rendahnya motivasi atau minat guru untuk menulis, keterbatasan keterampilan guru untuk menyusun karya ilmiah, serta kurangnya sosialisasi atau pelatihan yang terkait dengan karya tulis ilmiah (Noorjannah, 2014). Kondisi ini akan berdampak pada terkendalanya proses bagi guru dalam memenuhi kompetensi sebagai guru profesional.

Berdasarkan permasalahan tersebut, maka diperlukan suatu kegiatan pendampingan dan pelatihan dan pendampingan penulisan penelitian tindakan kelas dan karya ilmiah bagi para guru. Beberapa studi telah membuktikan bahwa kegiatan berupa pelatihan dan pendampingan cukup efektif dalam meningkatkan motivasi dan keterampilan guru menyusun karya tulis ilmiah (Fitria, Kristiawan, \& Rahmat, 2019; Miaz, Zuardi, \& Putra, 2020). Kegiatan pelatihan dan pendampingan ini akan difokuskan untuk meningkatkan kemampuan dan kemauan para guru untuk menulis karya ilmiah berupa penelitian tindakan kelas, artikel ilmiah, dan karya tulis ilmiah lainnya. Melalui program pelatihan dan pendampingan ini, guru akan memperoleh kesempatan untuk mengembangkan kompetensi terkait dengan penelitian tindakan kelas, kaidah-kaidah penulisan ilmiah, melakukan penelusuran dan pengkajian literature, menyusun kerangka konseptual karya ilmiah, serta kiat-kiat yang diperlukan dalam rangka mempublikasikan karya tulis ilmiah.

\section{Metode}

\section{Sasaran dan Waktu Kegiatan Pelatihan dan Pendampingan}

Program pelatihan dan pendampingan penulisan penelitian tindakan kelas dan karya tulis ilmiah online ini dilaksanakan pada tanggal 7 September - 18 September 2020 dengan peserta sejumlah 85 orang guru yang berasal dari SD, SMP, dan SMA/K yang berasal dari berbagai wilayah di Provinsi Bali.

\section{Metode Pelaksanaan Kegiatan}

Pelaksanaan program pelatihan dan pendampingan penulisan penelitian tindakan kelas dan karya tulis ilmiah ini dilakukan dengan metode online baik secara synchronize melalui aplikasi Zoom dan unsynchronized melalui aplikasi Whatsapp. Metode online dipilih mengingat pelaksanaan program ini dilakukan dalam kondisi pandemic COVID-19. Masing-masing tahap pelaksanaan dan rincian kegiatan digambarkan sebagai berikut. 


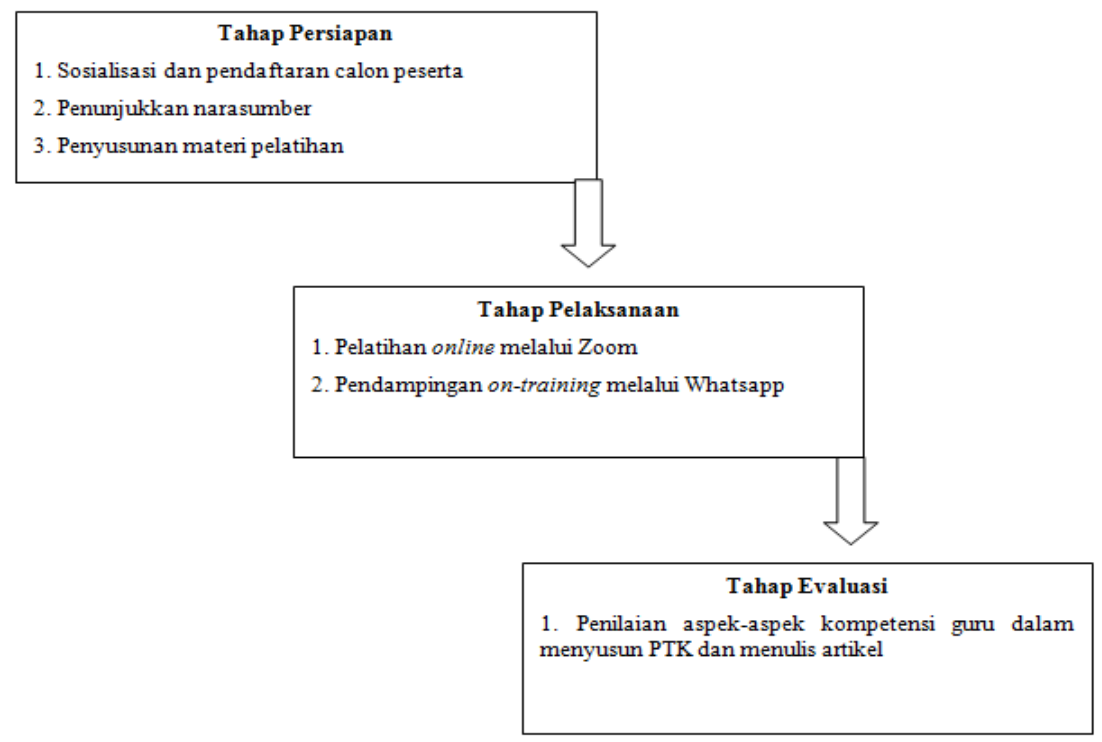

Gambar 1. Diagram Alur Tahap Pelaksanaan Program Pelatihan dan Pendampingan

\section{Metode dan Instrumen Evaluasi Kegiatan}

Program pelatihan dan pendampingan penyusunan PTK dan karya tulis ilmiah ini dievaluasi dengan instrumen evaluasi berupa kuesioner yang terkait dengan kompetensi dan kemauan peserta kegiatan yang meliputi beberapa aspek yakni (1) motivasi peserta untuk menyusun PTK dan mempublikasikannya, (2) keberhasilan mengidentifikasi permasalahan dan tema penelitian tindakan, (3) keberhasilan merumuskan solusi dalam tindakan pembelajaran yang digunakan mengatasi permasalahan, (4) keberhasilan menyusun draft proposal penelitian tindakan, dan (5) keberhasilan dalam menyusun draft artikel hasil penelitian tindakan. Hasil evaluasi digunakan sebagai indikator keberhasilan program yang dilaksanakan.

\section{Hasil dan Pembahasan \\ Deskripsi Pelaksanaan Kegiatan}

Program pelatihan dan pendampingan penyusunan PTK dan karya tulis ilmiah online ini diawali dengan tahap persiapan, yakni sosialisasi dan pendaftaran calon peserta. Sesuai dengan sasaran kegiatan yang ditujukan kepada guru yang bertugas di SD, SMP, dan SMA/K di wilayah Provinsi bali, maka surat undangan dan sosialisasi dilakukan dengan menghubungi pihak sekolah secara langsung melalui whatsapp serta mempublikasikan informasi terkait kegiatan pelatihan dan pendampingan melalui media sosial. Sejumlah 85 orang guru yang berasal dari beberapa kabupaten di Provinsi Bali mendaftarkan diri dan menjadi peserta dalam kegiatan ini. Persiapan juga dilakukan dengan menyusun materi pelatihan yang akan disajikan.

Program pelatihan dan pendampingan ini dilaksanakan dalam dua bentuk kegiatan yakni seminar online melalui media Zoom dengan materi yang akan dipaparkan oleh narasumber yakni meliputi (1) Konsep PTK dan (2) Pentingnya PTK bagi guru, dan pendampingan on training dengan memanfaatkan media grup whatsapp. Kegiatan on training ini ditujukan untuk mendampingi peserta menyusun naskah karya tulis ilmiah. Peserta juga diberikan materi pelatihan untuk menunjang kemampuannya dalam menyusun PTK dan mempublikasikan hasil penelitian tersebut dalam bentuk artikel ilmiah. Adapun materi tersebut meliputi (1) penelusuran sumber pustaka, (2) paraphrase dan menghindari plagiarism, (3) pengunaan program manajemen referensi (Mendeley), (4) gaya selingkung jurnal, dan (5) langkah-langkah submitting artikel ke jurnal. Dokumentasi pelaksanaan kegiatan seminar online melalui Zoom dapat diakses pada link https://www.youtube.com/watch?v=8ufk2WwWJ_g. 


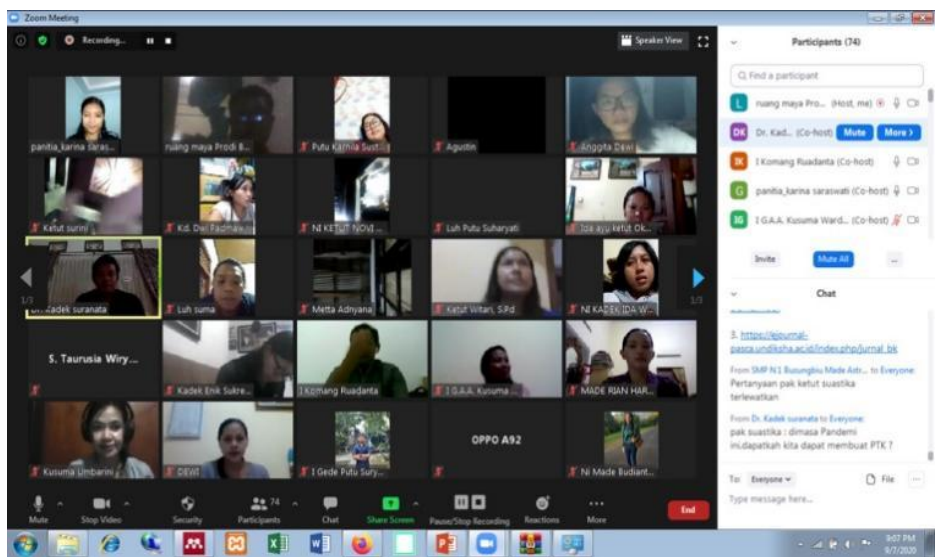

Gambar 2. Pelaksanaan Program melalui Zoom

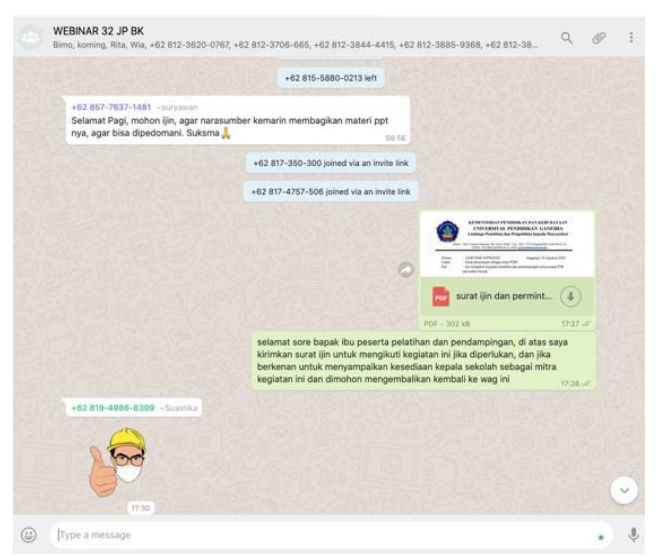

Gambar 3. Pelaksanaan Program melalui WhatsApp

\section{Hasil Pelaksanaan Kegiatan}

Hasil kegiatan pelatihan dan pendampingan ini dievaluasi dengan instrumen evaluasi berupa kuesioner yang menyangkut beberapa aspek meliputi (1) motivasi peserta untuk menyusun PTK dan mempublikasikannya, (2) keberhasilan mengidentifikasi permasalahan dan tema penelitian tindakan, (3) keberhasilan merumuskan solusi dalam tindakan pembelajaran yang digunakan mengatasi permasalahan, (4) keberhasilan menyusun draft proposal penelitian tindakan, dan (5) keberhasilan dalam menyusun draft artikel hasil penelitian tindakan. Adapun hasil evaluasi disajikan dalam diagram berikut.

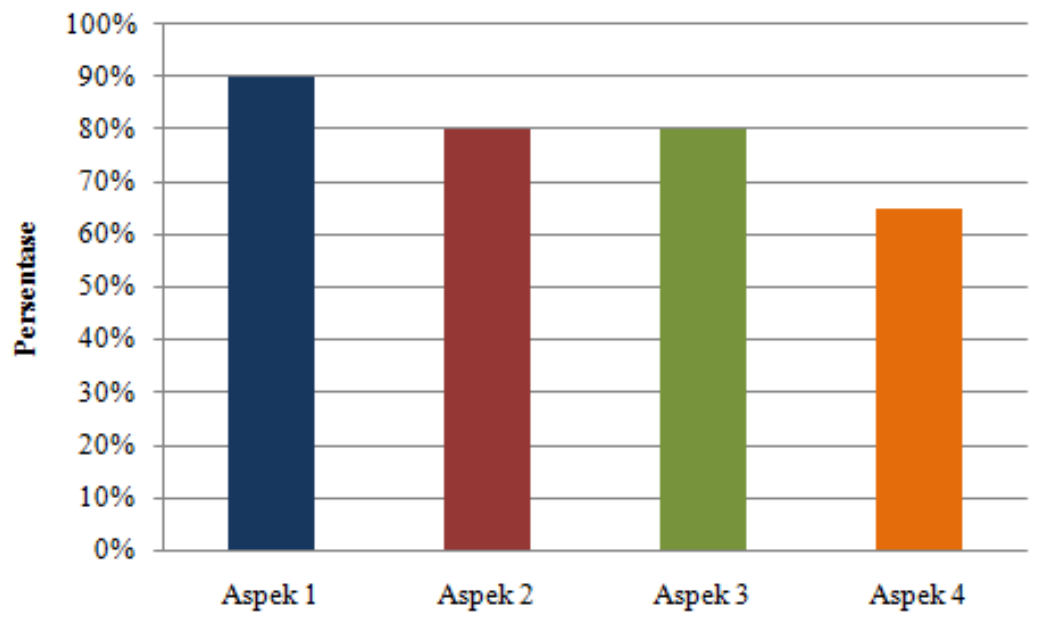

Grafik 1. Hasil Evaluasi Pelaksanaan Program Pelatihan dan Pendampingan 
Hasil analisis menunjukkan bahwa rata-rata $90 \%$ peserta mengalami peningkatan motivasi untuk menyusun PTK dan mempublikasikannya, $80 \%$ peserta telah berhasil mengidentifikasi permasalahan dan tema penelitian tindakan, $80 \%$ peserta mampu merumuskan solusi dalam tindakan pembelajaran yang digunakan mengatasi permasalahan, $75 \%$ peserta telah berhasil menyusun draft proposal penelitian tindakan, dan sejumlah $65 \%$ peserta telah berhasil menyusun draft artikel ilmiah hasil penelitian tindakan. Draft artikel yang telah disusun oleh peserta akan dilanjutkan dengan publikasi ke jurnal bereputasi nasional.

Berdasarkan hasil pelaksanaan program yang telah dilakukan dan dievaluasi, ditemukan bahwa melalui program pelatihan dan pendampingan penyusunan PTK dan karya tulis ilmiah online, peserta kegiatan yang merupakan guru-guru yang berasal dari beragam kabupaten di wilayah Provinsi Bali mengalami peningkatan motivasi untuk menyusun PTK dan mempublikasikannya. Dengan termotivasinya guru untuk melakukan penelitian tindakan kelas, maka akan berimplikasi pada meningkatnya hasil-hasil penelitian terkait pembelajaran yang akan menunjang perkembangan proses pendidikan.

Pelaksanaan program pelatihan dan pendampingan ini juga mampu meningkatkan kompetensi guru dalam merencanakan PTK, menyusun artikel ilmiah hasil PTK, dan menyiapkan artikel ilmiah untuk dipublikasikan ke jurnal bereputasi nasional. Disamping akan memperkaya kajian-kajian ilmiah terkait pembelajaran, kompetensi yang dimiliki oleh guru dalam menyusun karya tulis ilmiah akan menjadi poin tambahan dalam sertifikasi dan kenaikan pangkat yang akan meningkatkan kesejahteraan guru serta menunjang kualitas pribadi guru untuk menjadi guru profesional (Aisyah \& Mahanani, 2017; Handayani \& Rukmana, 2020).

Keberhasilan program pelatihan dan pendampingan ini juga didukung oleh penggunaan metode online. Selain digunakan untuk menyiasati kondisi pandemic COVID-19 yang mengharuskan adanya pembatasan sosial, metode pelatihan berbasis online cenderung mendapat respon yang lebih positif dari peserta dikarenakan waktu yang digunakan dalam pelatihan lebih fleksibel jika dibandingkan dengan pelatihan dengan metode klasikal (Munajatisari, 2014).

Terdapat beberapa hal yang dapat direkomendasikan dari hasil pelaksanaan program pelatihan dan pendampingan ini, diantaranya (1) kelompok kerja guru (MGMP atau sejenisnya) perlu memacu anggotanya agar produktif dalam melaksanakan beragam kegiatan ilmiah termasuk meneliti dan mempublikasikan hasil penelitian agar dapat diakses oleh banyak pihak, (2) dinas pendidikan dan instansi terkait dengan pengembangan karir guru perlu memberikan dorongan serta kebijakan terkait pengakuan poin kenaikan pangkat dari artikel ilmiah hasil penelitian agar memotivasi guru lebih produktif dalam menghasilkan karya ilmiah, dan (3) akademisi khususnya dosen perguruan tinggi agar dapat menjadi mitra kolaborasi guru untuk meneliti dan menghasilkan karya ilmiah.

\section{Simpulan}

Beragam upaya untuk meningkatkan kualitas dan kesejahteraan guru dilakukan oleh pemerintah, salah satunya melalui program sertifikasi guru. Dalam memenuhi kriteria sebagai guru profesional, guru perlu memiliki beberapa kompetensi, diantaranya adalah kompetensi dalam menghasilkan karya ilmiah. Penelitian tindakan kelas merupakan salah satu bentuk kegiatan ilmiah yang dapat dilakukan oleh guru. Program pelatihan dan pendampingan penyusunan PTK dan karya tulis ilmiah online bagi guru di Provinsi Bali merupakan salah satu kegiatan yang dilaksanakan dalam rangka mengembangkan kompetensi guru dalam menyusun, melaksanakan, dan mempublikasikan hasil-hasil penelitian tindakan kelas. Luaran dari kegiatan ini adalah artikel-artikel hasil penelitian tindakan yang akan dipublikasikan pada jurnal nasional.

\section{Referensi}

Afandi, M. (2014). Pentingnya Penelitian Tindakan Kelas Bagi Guru Dalam Pembelajaran di Sekolah Dasar. Jurnal Ilmiah "Pendidikan Dasar," 1(1).

Aisyah, E. N., \& Mahanani, P. (2017). Pelatihan Menulisan Artikel Ilmiah Bagi Guru Sekolah Dasar Dan Taman Kanak-Kanak Kecamatan Tajinan Kabupaten Malang. Abdimas Pedagogi, 1(1), 22-26.

Fitria, H., Kristiawan, M., \& Rahmat, N. (2019). Upaya Meningkatkan Kompetensi Guru Melalui Pelatihan Penelitian Tindakan Kelas. Abdimas Unwahas, 4(1), 14-25.

Handayani, S. L., \& Rukmana, D. (2020). Peningkatan Kemampuan Menulis Karya Ilmiah Guru Melalui Pelatihan Penelitian Tindakan Kelas bagi Guru SD. Publikasi Pendidikan, 10(1), 8. https://doi.org/10.26858/publikan.v10i1.9752

Miaz, Y., Zuardi, \& Putra, R. P. (2020). Pelatihan Penulisan Penelitian Tindakan Kelas Untuk Guru Sekolah Dasar. Jurnal Publikasi Pendidikan, 10(1), 19-25. 
Munajatisari, R. R. (2014). Analisis Efektivitas Metode Pelatihan Klasikal dan E-learning. Jurnal Administrasi Bisnis, 10(2), 173-185.

Ni'mah, Z. A. (2017). Urgensi Penelitian Tindakan Kelas Bagi Peningkatan Profesionalitas Guru: Antara Cita dan Fakta. Realita, 15(2), 1-11. https://doi.org/10.1016/j.det.2012.08.002

Noorjannah, L. (2014). Pengembangan Profesionalisme Guru Melalui Penulisan Karya Tulis Ilmiah Bagi Guru Profesional. Jurnal Humanity, 10(1), 97-114.

Permendiknas No. 18 Tahun 2007. tentang Sertifikasi Guru Dalam Jabatan.

Ridwan, A. S. S. (2017). Peningkatan Mutu Dikalangan Guru SD Dengan Kemampuan Penyusunan Proposal PTK. Jurnal Penjaminan Mutu, 3(1), 23-30.

Undang-Undang Nomor 14 Tahun 2005 tentang Guru dan Dosen. 